\title{
KEPATUHAN PERAWAT MENERAPKAN PEDOMAN KESELAMATAN KERJA DAN KEJADIAN CEDERA PADA PERAWAT INSTRUMEN DI INSTALASI BEDAH SENTRAL
}

\author{
Joko Pitoyo, Rudi Hamarno, Titis Elija Sa'adah \\ Poltekkes Kemenkes Malang Jl. Besar Ijen No 77C Malang \\ Email:jokpit22@gmail.com

\section{Compliance of Nurse Practice Safety Guidelines with Injured Events in Operating Room}

\begin{abstract}
This study aim is to determine the corrleation between compliance of nurse practice safety guidelines with injured events in operating room. The design of this research is a descriptive correlation. Sampling using a total sampling. The population of this research are all of intrumentator in operating room RSUD Dr Iskak Tulungagung whom work after a year of total sample 34 nurses. Data retrieval by using the observation sheet and quisioner sheet on May $25^{\text {th }}$ - June $15^{\text {th }} 2017$. After the data is retrieved and then do test the hypothesis by using the Chi Square Test. The results showed that of the total nurses in the category of submissive as much as 18 nurses $(52,94 \%)$ and most nurses get minor injuries as much as 25 nurses (73,5\%). Based on the analysis of the test results obtained the value $p$ of 0,011 (value $p<0,05$ ). Conclusion the is a correlation between compliance of nurse practice safety guidelines with injured events in operating room RSUD Dr Iskak Tulungagung.
\end{abstract}

Keywords: nurse compliance, guidelines for safety, injury

\begin{abstract}
Abstrak: Penelitian ini bertujuan untuk mengetahui hubungan kepatuhan perawat menerapkan pedoman keselamatan kerja dengan kejadian cedera di ruang operasi. Penelitian ini menggunakan desain penelitian deskriptif korelasi. Pengambilan sampel menggunakan Total Sampling. Populasi penelitian ini adalah seluruh perawat instrumen yang bekerja di Instalasi Bedah Sentral RSUD Dr Iskak Tulungagung yang telah bekerja di IBS Selama minimal 1 tahun dengan total sampel 34 perawat. Uji hipotesis dengan menggunakan uji Chi Square. Hasil penelitian menujukkan bahwa dari keseluruhan responden sebagian besar patuh sebanyak 18 perawat $(52,94 \%)$ dan sebagian besar perawat mengalami cedera ringan sebanyak 25 perawat (73,5\%). Berdasarkan hasil uji analisis didapatkan nilai $p$ value sebesar 0,011 (p value <0,05). Kesimpulan ada hubungan antara kepatuhan perawat dalam menerapkan pedoman keselamatan kerja dengan kejadian cedera pada perawat di IBS RSUD Dr Iskak Tulungagung.
\end{abstract}

Kata Kunci: kepatuhan perawat, pedoman keselamatan kerja, cedera

\section{PENDAHULUAN}

Keselamatan saat ini telah menjadi isu global di semua sektor, termasuk dalam sektor pelayanan kesehatan. Rumah sakit merupakan salah satu penyedia pelayanan kesehatan yang dituntut untuk senantiasa meningkatkan mutu pelayanan dengan membangun keselamatan dan layanan kesehatan yang lebih aman sehingga mendapat kepercayaan dari pelanggan. Keselamatan di rumah sakit merupakan aspek penting dan prinsip dasar layanan kesehatan serta komponen kritis dari manajemen mutu dan salah satu indikator dalam penilaian akreditasi rumah sakit (Kepmenkes No. 1087, 2010).

Perawat merupakan petugas kesehatan terbanyak dengan komposisi hampir $60 \%$ dari seluruh petugas kesehatan di rumah sakit dan yang melakukan kontak terlama dengan pasien. Perilaku keselamatan yang baik di kalangan perawat akan berdampak baik bagi kejadian cedera yang terjadi pada perawat. Rumah sakit merupakan tempat yang berbahaya bagi perawat. 
Perawat dapat terpapar berbagai macam risiko cidera dan penyakit saat bekerja. Petugas kesehatan berisiko lebih tinggi mengalami kecelakaan akibat kerja dan penyakit akibat kerja dibanding pekerja industri lain (Kepmenkes No. 1087, 2010). Penyakit akibat kerja dan kecelakaan akibat kerja pada perawat selain disebabkan oleh faktor lingkungan yang tidak aman (unsafe condition), juga dapat disebabkan oleh perilaku yang tidak aman (unsafe act). Sumakmur (2009) dalam Ayu (2012) menyatakan $85 \%$ sebab terjadinya penyakit akibat kerja dan kecelakaan akibat kerja bersumber pada faktor manusia. Risiko bahaya di rumah sakit mencakup bahaya biologik, fisik, kimia, ergonomik, dan psikososial (Kepmenkes No. 1087, 2010).

Perawat instrumen harus mengetahui bagaimana menggunakan peralatan dan teknologi secara aman untuk mencegah terjadinya bahaya fisik yang mengancam perawat instrumen. Maria (2015) menyatakan sebagian besar perawat $(54,5 \%)$ atau 54 orang melakukan unsafe action dalam bekerja dan sebagian besar $(25,3 \%)$ atau 25 orang perawat yang melakukan unsafe action adalah termasuk dalam kategori masa kerja lama ( $>10$ tahun) atau disebut perawat senior. Dengan jenis unsafe action terbanyak $(23,3 \%)$ adalah mengoperasikan peralatan kerja tidak sesuai standar. Perawat memiliki risiko untuk terpajan radiasi pengion seperti sinar-x, misalnya di ruang radiografi, ruang operasi, unit gawat darurat, dan unit perawatan intensif. Selain radiasi sinar pengion, penggunaan instrumen tajam juga mengancam keselamatan perawat di ruang operasi. Perilaku kesehatan dan keselamatan kerja perawat di rumah sakit sangat penting, karena tindakan perawat sekecil apapun dapat menimbulkan risiko terhadap perawat dan pasien (Potter \& Perry, 2005).

Perawat selain mengalami bahaya fisik dan kimiawi juga dapat mengalami cedera ergonomik yang serius akibat memindah pasien. Perawat mempunyai peluang besar mengalami low back pain (LBP) dan cedera muskuloskeletal di rumah sakit (Trinkoff, et al., 2002). Prevalensi perawat mengalami LBP $40-50 \%$ pertahun dan $35-80 \%$ sepanjang hidup dengan klaim kesehatan yang tertinggi (Edlich et al., 2004). Lebih dari sepertiga perawat pernah mengalami cedera punggung yang cukup parah yang menyebabkan perawat harus meninggalkan pekerjaan (Zerwekh \& Claborn, 2009). Kejadian LBP perawat di Rumah Sakit RSPI Prof DR. Sulianti Saroso dalam kategori tidak normal atau terjadi low back pain sebanyak 66\%, sedangkan frekuensi perawat dengan Kejadian LBP normal atau tidak terjadi Low Back Pain sebanyak 34\% (Sarwili, 2014).

Keselamatan sangat dibutuhkan oleh perawat saat bekerja. Keselamatan merupakan salah satu kebutuhan dasar manusia yang harus dipenuhi. Manajemen rumah sakit bertanggung jawab untuk membuat program manajemen risiko yang berkelanjutan untuk mengurangi dan mengidentifikasi kejadian yang tidak diinginkan dan risiko-risiko keselamatan lainnya pada pasien dan staf rumah sakit. Perawat seringkali kurang peduli terhadap bahaya di tempat kerja dan dalam melakukan upaya proteksi diri meskipun perawat tahu hal tersebut dapat membahayakan keehatan dan nyawa perawat.

Perilaku perawat dalam bekerja dipandu melalui pedoman kerja. Selain standar operasional prosedur (SOP) dan standar asuhan keperawatan (SAK) sebagai pedoman perawat dalam bekerja, panduan keselamatan perawat diperlukan untuk memandu perawat berperilaku aman dan selamat dalam bekerja. Oleh karena itu, protokol keamanan untuk perawat dan pasien harus diikuti dan dipraktikkan dengan baik.

Hasil studi pendahuluan yang telah dilakukan pada bulan Februari sampai April di IBS RSUD Dr Iskak Tulungagung peneliti mendapati beberapa perawat selalu menggunakan masker yang sama selama berada di ruang operasi atau 
menggunakan sarung tangan yang sama pada satu pasien meskipun telah terkontaminasi cairan tubuh pasien tersebut. Hasil pengamatan juga menunjukkan selama periode waktu 3 bulan terjadi satu kejadian cedera serius yang dialami oleh perawat, yaitu tertusuk jarum cutting saat menjahit pasien dengan diagnosis B24 positif.

Sampai saat ini, belum banyak penelitian yang terkait dengan kesehatan dan keselamatan kerja perawat di rumah sakit khususnya perawat instrumen dikamar operasi. Program kesehatan dan keselamtan kerja memiliki pengaruh positif terhadap peningkatan produktivitas kerja karyawan karena membentuk pengetahuan, keterampilan dan sikap yang baik terhadap kesehatan dan keselamatan kerja sehingga dapat mencegah atau mengurangi kerugian-kerugian akibat penyakit akibat kerja dan kecelakaan akibat kerja.

Tujuan penelitian ini mengetahui hubungan kepatuhan perawat dalam menerapkan pedoman keselamatan kerja dengan kejadian cedera pada perawat di Instalasi Bedah Sentral RSUD Dr Iskak Tulungagung.

\section{METODE PENELITIAN}

Desain penelitian ini adalah studi korelasional. Pada penelitian korelasi, peneliti mencoba mencari hubungan antara kepatuhan perawat dalam menerapkan pedoman keselamatan kerja dengan kejadian cedera pada perawat di Instalasi Bedah Sentral RSUD Dr Iskak Tulungagung.

Sampel penelitian ini adalah seluruh perawat instrumen yang bekerja di Instalasi Bedah Sentral RSUD Dr Iskak Tulungagung yang masuk dalam kriteria inklusi pada tanggal 25 Mei-15 Juni 2017 sebanyak 34 responden.

Metode pengumpulan data adalah menggunakan observasi dan kuisioner. Observasi berupa lembar pencatatan yang berisi hasil observasi mengenai kepatuhan perawat dalam menerapkan pedoman keselamatan kerja yang telah dimodifikasi oleh peneliti, dan kuisioner berisi pernyataan tentang pengalaman cedera yang pernah dialami oleh perawat di Instalasi Bedah Sentral RSUD Dr Iskak Tulungagung.

Pengolahan data dengan menggunakan skoring. Skoring yaitu jawaban benar (diharapkan) diberi skor 1 dan jika salah (tidak diharapkan) skor 0, hasil skor responden dari semua pertanyaan dijumlahkan lalu dibandingkan dengan skor tertinggi yaang diharapkan dan dikalikan $100 \%$. Analisis data menggunakan persentase.

\section{HASIL PENELITIAN}

Karakteristik responden berdasarkan jenis kelamin didapatkan sebagian besar adalah lakilaki dengan persentase $61,76 \%$ (21 orang) dari total 34 perawat instrumen, dan 13 lainnya adalah perempuan. Berdasarkan usia didapatkan rentang umur 31-40 tahun yaitu sebanyak 67,65\% (23 perawat) dari total 34 perawat. Berdasarkan Tingkat pendidikan lebih dari setengah perawat instrumen di IBS RSUD Dr Iskak Tulungagung adalah Diploma 3 sebesar 73,53\% (25 orang) dari total 34 perawat instrumen. masa kerja antara 1 sampai 10 tahun yaitu sebanyak $76,46 \%$ atau sebanyak 26 perawat dari total 34 perawat.

Tabel 1. Tabel Kepatuhan Penerapan Pedoman Keselamatan Perawat

\begin{tabular}{lcc}
\hline Tingkat Kepatuhan & F & \% \\
\hline Patuh $(100 \%)$ & 18 & 52,94 \\
Tidak Patuh $(<100 \%)$ & 16 & 47,06 \\
\hline Total & 34 & 100 \\
\hline
\end{tabular}

Tabel 2. Kejadian Cedera pada Perawat

\begin{tabular}{lcc}
\hline Kejadian Cedera & F & $\mathbf{\%}$ \\
\hline Berat (11-14) & - & - \\
Sedang (8-10) & 4 & 11,76 \\
Ringan (1-7) & 25 & 73,54 \\
Tidak Cedera (0) & 5 & 14,70 \\
\hline Total & 34 & 100 \\
\hline
\end{tabular}


Hasil penelitian didapatkan tingkat kepatuhan perawat dalam menerapkan pedoman keselamatan kerja perawat adalah patuh sebanyak 52,94\% dan tidak patuh 47,06\%. Hasil dapat dilihat pada Tabel 1.

Dari Tabel 2 diketahui bahwa lebih dari setengah perawat $(73,54 \%)$ mengalami cidera ringan di kamar operasi, baik selama prosedur pembedahan maupun diluar prosedur pembedahan, sisanya $(11,76 \%)$ mengalami cidera sedang selama berada di kamar operasi.

Hasil analisis statistik dengan cross tabulasi antara kepatuhan perawat dengan kejadian cedera didapatkan hasil uji statistik chi square didapatkan nilai signifikansi $=0,011$ lebih kecil dari $\alpha(0,05)$, maka $\mathrm{H} 1$ diterima sehingga ada hubungan antara kepatuhan perawat dalam menerapkan pedoman keselamatan kerja perawat dengan kejadian cedera pada perawat instrumen.

\section{PEMBAHASAN}

Kepatuhan perawat dalam menerapkan pedoman keselamatan kerja perawat instrumen dipengaruhi oleh banyak faktor diantaranya jenis kelamin, umur, tingkat pendidikan, dan pengalaman kerja yang telah dilalui. Hasil penelitian menunjukkan bahwa perawat instrumen di IBS RSUD Dr Iskak Tulungagug sebagian besar adalah laki-laki dengan persentase $61,76 \%$ (21 orang) dari total 34 perawat instrumen, dan 13 lainnya adalah perempuan. Menurut Triwidyawati (2013) pada umumnya wanita lebih patuh pada saat melakukan tindakan dari pada pria karena wanita lebih peduli.

Hasil penelitian menunjukkan bahwa lebih dari setengah perawat instrumen memiliki rentang umur 31-40 tahun yaitu sebanyak 67,65\% (23 perawat) dari total 34 perawat. Hal ini menunjukkan bahwa responden memiliki usia yang matang dalam berfikir dan bekerja atau usia produktif. Sejalan dengan pendapat Nursalam
(2008) bahwa semakin cukup umur, tingkat kematangan dan kekuatan seseorang akan lebih matang dalam berfikir dan bekerja.

Penelitian didapatkan hasil bahwa tingkat pendidikan lebih dari setengah perawat instrumen di IBS RSUD Dr Iskak Tulungagung adalah Diploma 3 sebesar 73,53\% (25 orang) dari total 34 perawat instrumen. Pendidikan bagi seorang perawat merupakan faktor penting sehingga kinerja perawat dalam melakukan pelayanan mendapatkan hasil yang maksimal. Hal ini sejalan dengan penelitian Oktaviani (2015) bahwa tingkat pendidikan perawat dengan rasio akademik lebih banyak akan memudahkan dalam menerima serta mengembangkan pengetahuan dan teknologi.

Hasil penelitian didapatkan hasil bahwa sebagian besar perawat memiliki masa kerja antara 1 sampai 10 tahun yaitu sebanyak 76,46\% atau sebanyak 26 perawat dari total 34 perawat. Semakin lama seseorang bekerja semakin banyak kasus yang ditanganinya sehingga semakin meningkat pengalamannya, sebaliknya semakin singkat orang bekerja maka semakin sedikit kasus yang ditanganinya. Hal ini sejalan dengan penelitian Triwidyawati (2013) yang mengatakan bahwa sebagian besar perawat dengan masa kerja yang baru belum banyak pengetahuan dan pengalaman yang dimiliki dibandingkan dengan perawat yang sudah bekerja lama.

Hasil penelitian didapatkan bahwa tingkat kepatuhan lebih dari setengah perawat dalam menerapkan pedoman keselamatan kerja di IBS RSUD Dr Iskak Tulungagung yaitu 52,94\% masuk dalam kategori patuh, dan sisanya $(47,06 \%)$ dalam kategori tidak patuh. Dalam melakukan pelayanan keperawatan, kepatuhan terhadap pedoman keselamatan sangat membantu perawat dalam meberikan kinerja yang maksimal.

Dalam penilaian kejadian cedera pada perawat menggunakan lembar kuisioner yang memuat riwayat cedera yang pernah dialami oleh 
perawat selama 3 bulan terakhir. Dari 34 perawat yang menjadi responden penelitian ada 4 perawat yang mengalami cidera sedang, paling sering yaitu pada kejadian dehidrasi, ketumpahan cairan kimia seperti formaldehida dan eter, merasakan nyeri punggung, tersengat stik diatermi, hingga luka bakar akibat tersengat stik diatermi.

Penyebab kecelakaan atau cedera salah satunya adalah kebiasaan dimana terdapat suatu keadaan lingkungan tidak aman (unsafe condition) atau tindakan yang tidak memenuhi keselamatan (unsafe act). Seringkali kecelakaan merupakan kombinasi dari kedua faktor tersebut. Pada penelitian ini kejadian cedera pada perawat bisa terjadi karena dipengaruhi oleh tindakan yang tidak memenuhi keselamatan (unsafe act) dalam hal ini adalah kepatuhan dalam menerapkan pedoman keselamatan kerja. Hal ini sejalan dengan penelitian Hidayat (2013) yang menyatakan bahwa perilaku tidak aman (unsfae action) berpengaruh positif dan signifikan terhadap kecelakaan kerja. Masih dalam penelitian yang sama menyatakn bahwa nilai besaran pengaruh perilaku tidak aman (unsafe action) adalah $22 \%$ yang artinya positif memberikan pengaruh terhadap angka kecelakaan kerja. Sedangkan besaran pengaruh kondisi tidak aman (unsafe condition) berdasarkan analisa SEM adalah - $0.92 \%$ yang berarti bahwa pengaruh terhadap angka kecelakaan kerja jauh lebih kecil dari perilaku tidak aman.

Berdasarkan hasil cross tabulasi antara kepatuhan perawat dengan kejadian cedera didapatkan hasil uji statistik chi square didapatkan nilai signifikansi $=0,011$ lebih kecil dari $\alpha(0,05)$, maka $\mathrm{H} 1$ diterima sehingga ada hubungan antara kepatuhan perawat dalam menerapkan pedoman keselamatan kerja perawat dengan kejadian cedera pada perawat instrumen. Kejadian cedera dapat terjadi dipengaruhi oleh banyak faktor, salah satunya adalah kepatuhan perawat dalam menerapkan pedoman keselamatan kerja yang ada di ruang operasi. Kepatuhan merupakan salah satu hal yang mempengaruhi dalam tindakan yang tidak aman (unsafe action).

\section{PENUTUP}

Tingkat kepatuhan perawat dalam menerapkan pedoman keselamatan kerja berhubungan dengan kejadian cedera yang dialami oleh perawat di kamar operasi RSUD Dr Iskak Tulungagung. Lebih dari setengah responden memiliki tingkat kepatuhan yang baik tidak mengalami cedera, dan sebagian mengalami cedera ringan, namun selebihnya perawat yang tidak patuh dalam menerapkan pedoman keselamatan kerja mengalami cedera sedang dan sebagian mengalami cedera ringan. Ketidakpatuhan perawat paling banyak terjadi pada penggunaan alat pelindung diri yang belum sesuai standar pemakaian, sehingga menjadi salah satu faktor penyebab cedera pada perawat di kamar operasi.

Penggunaan alat pelindung diri (APD) lengkap dengan cara yang benar dapat menurunkan angka kejadian cedera di kamar operasi, sehingga perlu adanya pengadaan APD standar dan sosialisasi penggunaannya kepada perawat. Guna meningkatkan kepatuhan perawat dalam menerapkan pedoman keselamatan kerja untuk mengurangi angka kejadian cedera, diharapkan adanya pelatihan terkait kesehatan dan keselamatan kerja rumah sakit berkala setiap enam bulan agar peningkatan perilaku kesehatan dan keselamatan kerja dapat bersifat permanen. Perlu dilakukan supervisi berkala setiap bulan untuk mengecek kepatuhan perawat menerapkan standar prosedur operasional yang berlaku di ruangan, sehingga dapat dilakukan evaluasi pedoman yang belum patuh dilaksanakan. 


\section{DAFTAR PUSTAKA}

Ayu, N.M. (2012). Pengaruh Penggunaan Panduan Keselamatan Perawat Terhadap Perilaku Kesehatan dan Keselamtan Kerja Perawat Di Rumah Sakit Siaga Raya. Depok. Tesis FIK-UI tidak dipublikasikan.

Hidayat, D. (2013). Pengaruh Perilaku Tidak Aman (Unsafe Action) dan Kondisi Tidak Aman (Unsafe Condition) terhadap Kecelakaan Kerja Karyawan di Lingkungan PT. Freyabadi Indotama. Purwakarta: Jurnal Ilmiah Sekolah Tinggi Teknologi Wastu Kancana.

Kepmenkes No. 1087 Tahun 2010. Diakses pada 3 September 2016 dari http:// www.depkes.go.id/downloads/ Kepmenkes/Kepmenkes_ 1087 _Th_2010.pdf.

Oktaviani, H. (2015). Hubungan Pengetahuan dengan Kepatuhan Perawat dalam Pelaksanaan Standar Prosedur Operasional Pencegahan Risiko Jatuh Pasien di Rumah
Sakit Panti Waluyo Surakarta. Surakarta: Skripsi STIKES Kusuma Husada.

Potter, P. A. \& Perry, A. G. (2005). Buku Ajar Fundamental Keperawatan: Konsep, Proses, dan Praktik Edisi 4 Volume 1. Jakarta: EGC.

Sarwili, I. (2014). Hubungan Beban Kerja Perawat Terhadap Angka Kejadian Low Back Pain (LBP). Jakarta: Artikel Penelitian Sekolah Tinggi Ilmu Kesehatan Indonesia Maju.

Triwidyawati, D. (2013). Hubungan Kepatuhan Perawat dalam Menjalankan SOP Pemasangan Infus dengan Kejadian Phlebitis. Semarang: Jurnal Penelitian STIKES Telogorejo Semarang.

Zerwekh, J., \& Claborn, J. C. (2009). Nursing today: transition and trends. 6th edition. Missouri: Saunders Alsevier. 